\title{
The Effect of Intervaling on the Foreign Exchange Exposure of Australian Stock Returns*
}

\author{
Amalia Di lorio \\ RMIT University, Australia \\ Robert Faff \\ RMIT University, Australia
}

\begin{abstract}
This article analyzes the impact of movements in the Australian dollar/Japanese yen (AUDJPY) and the Australian dollar/US dollar (AUDUSD) exchange rates on the returns of the Australian equities market. Specifically, this paper investigates the nature of exchange rate exposure across increasing return measurement intervals, enabling an examination of both its short-term and its long-term effect on stock returns. Consistent with previous literature, considerable evidence of long-term exchange rate exposure is found. Further, it is found that in the long-term the Australian equities market in general is exposed to fluctuations in the AUDJPY, while only some Australian industries are exposed to movements in the AUDUSD. Finally, convincing evidence in terms of the determinants of foreign exchange exposure is not found (JEL G12, G15).
\end{abstract}

Keywords: Australian stock market, exchange rate risk, intervaling.

\section{Introduction}

Since the publication of the study by Jorion (1990), who failed to find strong evidence of foreign exchange exposure for US multinational firms, numerous investigations have been undertaken in an attempt to investigate the relationship between stock returns and fluctuations in the exchange rate. For example, Loudon (1993) who investigates a sample

*The authors wish to express their gratitude to Mark Stewart for his assistance.

(Multinational Finance Journal, 2001, vol. 5, no. 1, pp. 1-33)

CMultinational Finance Society, a nonprofit corporation. All rights reserved.

DOI: $10.17578 / 5-1-1$ 
of Australian companies, reports only six percent of the sample with statistically significant coefficients. These weak results are consistent with those found by other studies, for example, Khoo (1994); Amihud (1994); and Bartov and Bodnar (1994) who all report a low incidence of statistically significant coefficients.

The inability to satisfactorily measure the relationship between foreign exchange exposure and stock returns has encouraged researchers to explore a number of research design issues. ${ }^{1}$ These issues include lagged exposures [see, for example, Bartov and Bodnar (1994); Shin and Soenen (1999); Di Iorio and Faff (2000)]; data frequency [see, for example, Chamberlain et al. (1997); Di Iorio and Faff (2000)]; and industry-level versus firm-specific analysis [see, for example, Bodnar and Gentry (1993); Prasad and Rajan (1995); and Di Iorio and Faff (2000)]. A further issue that offers great promise is lengthening the return measurement interval. On this score, Chow et al. (1997a, b) argue short-horizon returns contain errors made by investors in forecasting the long-term effects of current exchange rate changes and find evidence that the foreign exchange exposure of individual firms increases with lengthening return horizons. Chow and Chen (1998) also employ different time horizons to investigate foreign exchange exposure. In keeping with Chow et al. (1997 a,b) and Chow and Chen (1998), the current study examines the impact of intervaling on the foreign exchange exposure of Australian stock returns by implementing long-term horizons.

First, using a time-series framework this paper analyzes the twentyfour industries of the Australian Stock Exchange and investigates how an appreciation of the Australian dollar against i) the US dollar; and ii) the Japanese yen, impacts on shareholder wealth. This analysis is undertaken by implementing the AUDUSD and AUDJPY bilateral exchange rate returns in separate augmented market models. Second, in keeping with Bodnar and Gentry (1993), a cross-sectional analysis is

1. Prior research has also investigated the relation of the second moments, for example, Bartov, Bodnar and Kaul (1996). More recently, Baum et al. (2000) develop an analytical framework to examine the volatility of exchange rates with respect to volatility of the firms profitability. In so doing, Baum et al. (2000) investigate the effects of permanent and transitory components of the exchange rate on firms' profitability. Although this proves an interesting area of research, it remains outside the scope of the current study. 
used to investigate the impact of exchange rate changes on importers, exporters, users of internationally-priced inputs and non-traded industries. $^{2}$

The current study extends the analysis of the exchange rate exposure of the Australian equities market undertaken by Di Iorio and Faff (2000). Notably, while both investigations employ (i) industry portfolios; and (ii) the AUDUSD and AUDJPY exchange rate factor returns, the two studies are distinguished by their focus. Specifically, Di Iorio and Faff (2000) use a dummy variable specification to analyze the potential asymmetric effect induced by non-linear hedging strategies, such as currency options, for the period 1988 to 1996. The current study, however, investigates the nature of exchange rate exposure across increasing time horizons for the period 1988 to 1998 . This enables the analysis of the short-term and the long-term effects of this type of (symmetric) exposure on stock returns.

Since this study employs Australian data, another important contribution is the investigation of foreign exchange exposure using alternative data compared to the majority of the literature which is US based. The current study follows the general argument of Leamer (1983) and of Lo and MacKinlay (1990) regarding the concern of data snooping in finance research. Similar justification has been used elsewhere - see for example, Jagannathan et al. (1998) who use Japanese data to test a labor-income based CAPM [of Jagannathan and Wang (1996)] and Clare et al. $(1997,1998)$ who use UK data to test the CAPM using a one-step procedure.

The remainder of this paper is structured as follows: the empirical framework is outlined in Section 2, the data and the results of the analysis are reported and discussed in Section 3, while a summary is provided in Section 4.

\section{Empirical Framework}

\section{A. Time Series Analysis}

Consistent with the approach described by Adler and Dumas (1984) and

2. Bodnar and Gentry (1993) also investigate foreign investors. However due to lack of data, this study does not examine their exchange rate exposure. 
the empirical methodology employed in previous studies [see, for example, Jorion (1990); Loudon (1993); Chamberlain et al (1997); Shin and Soenen (1999); Di Iorio and Faff (2000)], the exchange rate exposure of individual industries is measured as the slope coefficient using the following augmented market model (expressed in Australian dollar terms):

$$
R_{i t, t+T}=\alpha_{i}+\beta_{i} R_{m t, t+T}+\gamma_{i} X R_{t, t+T}+e_{i t, t+T},
$$

where $R_{i t, t+T}$ is the return on the ith asset or portfolio on horizon/interval from $t$ to $t+T, R_{m t, t+T}$ is the return on the market index on horizon/interval from $t$ to $t+T$, and $X R_{t, t+T}$ is the return on the exchange rate factor on horizon/interval from $t$ to $t+T$. An appreciation (depreciation) of the Australian dollar will produce a positive (negative) value for $X R_{t, t+T}$, where $T$ equals $1,2,5,20$ and 50 days when using daily 'base' data and $1,3,6,12,24,36$ and 48 months when employing monthly 'base' data. By the very nature of this analysis, in order to achieve adequate sample sizes, overlapping observations result for return horizons greater than one day and one month, respectively. Furthermore, in an attempt to resolve the problem of autocorrelated error terms arising from the overlapping horizons, Hansen's (1982) generalized method of moments (GMM) technique is implemented. This method adjusts the variancecovariance matrix of the estimated coefficients for both heteroskedasticity and autocorrelation in the error terms.

This investigation involves two variants of the exchange rate factor, namely, (1) against the US dollar (AUDUSD); and (2) against the Japanese yen (AUDJPY). The choice of the AUDUSD and the AUDJPY exchange rates is supported by the fact that Japan and the US are Australia's two most important trading partners. Over the period 1988 to 1998, Japan has been Australia's most important trade partner, averaging almost 21 percent of total trade over this period. ${ }^{3}$ This is closely followed by the US, which has averaged 15.5 percent. It should also be noted that an independent survey of Australian businesses indicates that $55 \%$ of all export contracts are written against the US dollar, including the majority of commodity contracts. ${ }^{4}$

3. Australian Bureau of Statistics: International Merchandise Trade Cat. No. 5422.

4. Australian Society of Corporate Treasurers (1995) Independent Survey of the 


\section{B. Cross-Sectional Analysis}

Prior research has examined a number of firm and industry characteristics in an attempt to establish the determinants of exchange rate exposure [see, for example, Jorion (1990), Booth and Rotenburg (1990); Bodnar and Gentry (1993); Amihud (1994); Prasad and Rajan (1995); He and Ng (1998); Chow and Chen (1998); and Shin and Soenen (1999)]. ${ }^{5}$ In their cross-sectional analysis, Bodnar and Gentry (1993) investigate industry-level exchange rate exposure for Canada, Japan and the US. Using economic theory, they attempt to predict the effect of changes in the exchange rate based on industry characteristics. They find that an appreciation of the home currency has a positive effect on importers, non-traded good producers, and users of internationally-priced inputs and a negative effect on import competitors, exporters and foreign investors. They argue that an appreciation reduces cash flows (in terms of the home currency) of exporters because it causes a combination of decreased foreign demand and a lower pricecost margin. Conversely, an appreciation increases cash flows of importers through increased demand and a higher price cost margins. At the same time the increased price competitiveness of foreign imports results in lower demand and smaller margins for import-competing firms. However, those firms that use internationally-priced inputs, (whether they are imported or priced on world markets), experience increased profitability with an appreciation of the home-currency. The homecurrency price of these inputs would decrease which translates into lower production costs and ultimately higher cash flows for the firm.

Following Bodnar and Gentry (1993), the current study investigates the determinants of foreign exchange exposure using the industry characteristics: import and export activity, internationally-priced inputs and non-traded goods. Data derived from the Australian Bureau of Statistics (ABS) Input-Output tables for 1993-1994 is used to capture these characteristics in the twenty-four industry portfolios as classified by the Australian Stock Exchange. ${ }^{6}$ Specifically, in order to obtain a

Australian Financial Review newspaper.

5. Booth (1996) analyzes the economic determinants of foreign exchange exposure within the boundaries of a theoretical model. The author shows that exposure depends on the segmentation of markets, the size of transaction costs, the behavior or real exchange rates, the firm's production flexibility and the price elasticity of demand.

6. It should be noted that the Australian Stock Exchange (ASX) partitions the stock 
measure for exports, an export (input-output) coefficient was calculated by dividing Total Exports for each industry by the Final Demand for that industry. Similarly, the import (input-output) coefficient was calculated by dividing Total Imports for each industry by the total Australian Production for that industry. However, rather than considering imports in general, two categories of imports are identified, namely competing imports (that have domestically produced substitutes) and complementary imports (that do not have domestically produced substitutes). Although both types of imports will benefit from appreciations of the home currency, the extent to which industries will benefit may differ between the two. Specifically, given a depreciation of the Australian dollar, one may expect to observe a stronger impact on competing imports than on complementary imports since competing imports have domestic substitutes. Next, relative Input-Output coefficients were estimated. ${ }^{7}$ Economic theory suggests that industries with a high relative (input-output) export measure, other things equal, would experience negative exchange rate exposure relative to an appreciation of the exchange rate factor, while industries with a high relative (input-output) import measure would experience positive exchange rate exposure.

Again following Bodnar and Gentry (1993), this investigation differentiates between traded and non-traded goods by creating a dummy variable for non-traded goods. Using the matching process between ABS classifications and ASX industry categories, the nontraded industries of the Australian equities market are taken to be: ASX 6Developers and Contractors; ASX 13 Retail; ASX 14 Transport; ASX 15 Media; ASX 16 Banks; ASX 17 Insurance; ASX 18 Entrepreneurial Investors; ASX 19 Investment and Finance; ASX 20 Property Trusts; ASX 21 Miscellaneous Services; ASX 22 Miscellaneous Industrials; and ASX 24 Tourism and Leisure. Further, internationally-priced imports were measured by estimating a relative Input-Output coefficient based on the percentage of Petroleum and Coal Products of Australian Production, since these products are priced in US dollars on the

market into twenty-four industry categories of which five (ASX Industries 1-5) are in the mining and resources sector and nineteen (ASX Industries 6-24) are in the industrial sector. The Australian Bureau of Statistics, on the other hand, broadly classifies Australian industries into thirty-five different sectors. Consequently, the ASX industry classifications and the ABS industry classifications are not completely compatible.

7. The relative Input-Output measure was calculated as the ratio of a particular industry's coefficient to the average Input-Output coefficient across all industries. 
international market.

The regression model that establishes the statistical significance of the determinants discussed above is:

$$
\begin{aligned}
& \gamma_{i}=C_{1}+C_{2} \text { CPIMPS }_{i}+C_{3} \text { CTIMPS }_{i}+C_{4} \text { OIL }_{i} \\
& (+) \quad(+) \quad(+) \\
& +C_{5} R E C_{i}+C_{6} N_{(-)} O N T R A D_{i}+C_{7} \beta_{i}+e_{i},
\end{aligned}
$$

where $\gamma_{i}$ is the exchange rate exposure coefficient derived in equation (1) for each industry, CPIMPS is the complementary import dummy; ${ }^{8}$ CTIMPS is the relative (input-output) competing import coefficient; OIL is the Petroleum and Coal Products relative Input-Output coefficient; $R E C$ is the relative export coefficient; and NONTRAD is the non-traded industry dummy variable. Further, the industry beta risk $\beta_{i}$ derived in equation (1) is controlled for by its inclusion in equation (2). The expected sign for each potential determinant is stated below the respective coefficient. ${ }^{9}$

\section{Data and Results}

\section{A. Data}

The data employed are continuously compounded daily returns and monthly returns on the twenty-four Australian industry indices as classified by the ASX, obtained from Datastream. The analysis covers the period from 1 January 1988 to 30 September 1998 and involves (a) 2723 daily observations and (b) 128 monthly observations. It should be noted that for nineteen industries complete data over this sample period

8. Since the relative Input-Output coefficients for complementary imports were similar in magnitude, a dummy variable is employed to avoid the problem of multicollinearity.

9. NONTRAD and $\beta_{i}$ are omitted from our analysis since these variables are highly correlated to the remaining four. A regression analysis of this form is undertaken, as well as regression analysis that simply captures the import/export characteristics. Specifically, by eliminating the variable for internationally-priced inputs and consolidating the complementary and competing import variables, the analysis is reduced to a basic form and only the cross-sectional analysis in relation to imports and exports is undertaken. 
TABLE 1. Summary Statistics for AUDUSD and AUDJPY for the Period January 1, 1988 to September 30, 1998

\begin{tabular}{lrr}
\hline & AUDUSD & AUDJPY \\
\hline Median & 0.7550 & 88.3854 \\
Maximum & 0.8950 & 122.6408 \\
Minimum & 0.5563 & 59.4719 \\
Standard Deviation & 0.0533 & 14.8316 \\
Skewness & -0.6214 & 0.0620 \\
Kurtosis & 3.7255 & 2.0409 \\
\hline
\end{tabular}

are employed. Data for the remaining five industries are as follows: (i) Solid Fuels (ASX3); Oil and Gas (ASX4); and Entrepreneurial Investors (ASX18) extends from 1 January 1988 to 29 October 1996; (ii) Miscellaneous Industrials (ASX22) extends from 3 January 1991 to 30 September 1998; and (iii) Tourism and Leisure (ASX24) extends from 8 August 1994 to 30 September 1998. The proxy for the market portfolio used is the All Ordinaries Accumulation Index supplied by Datastream, while the exchange rate factor return is based on both the AUDUSD and the AUDJPY, also obtained from Datastream.

The exchange rates are graphed for the sample period in figure 1 and the summary statistics are presented in table 1. It is observed that for the sample period analyzed, the AUDUSD exchange rate reached a maximum of US\$ 0.895 per Australian dollar and fell to a minimum of US\$0.5563. In the same period, the AUDJPY exchange rate ranged from a maximum of Y122.64 to a minimum of Y59.47 per Australian dollar. Further, it is noted that there is greater (relative) volatility attached to the AUDJPY exchange rate. Specifically, the standard deviation of the AUDUSD exchange rate (relative to its mean value) is $7.1 \%(.0533 / .7463)$, compared to the counterpart value of $16.3 \%$ (14.83/91.09) for the AUDJPY exchange rate.

\section{B. Foreign Exchange Exposure - Overlapping Analysis Employing Daily Base Data}

The exchange rate exposure coefficients from estimating equation (1) for 1 day, 2 day, 5 day, 20 day and 50 day measurement intervals are reported in tables 2 and $3 .{ }^{10}$ Specifically, the results of the analysis using

10. To conserve space, the intercept terms and the beta coefficients (all statistically significant), are not reported here. 

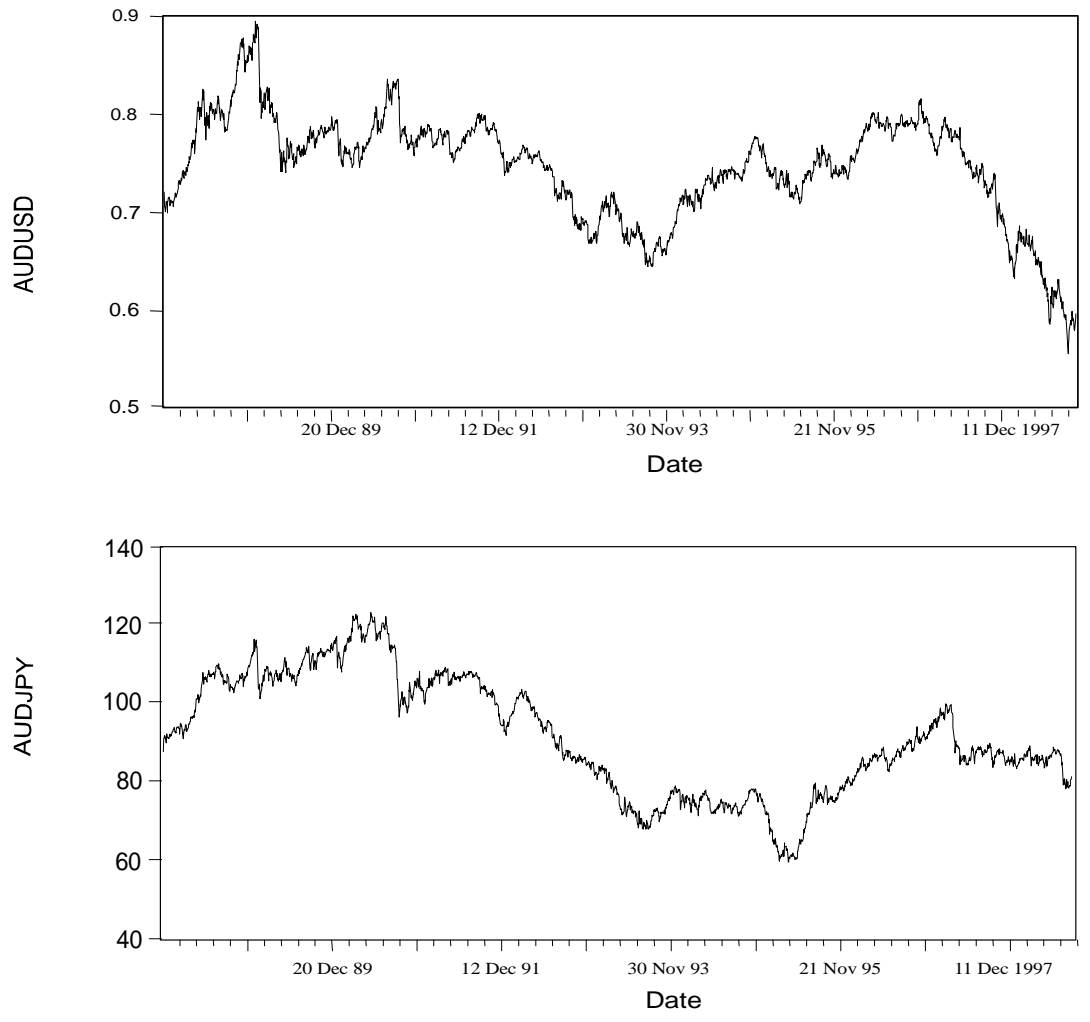

FIGURE 1.-The Australian dollar/US dollar exchange rate and the Australian dollar/Japanese yen exchange rate for January 1, 1988 to September 30, 1998: Daily Data.

the AUDJPY exchange rate return are reported in table 2 and the results from the analysis employing the AUDUSD exchange rate return are reported in table 3 . In both cases, the findings appear to generally confirm those of Chow et al. (1997 a,b) - there is a general increase in the number of statistically significant exchange rate return coefficients from the one day horizon to the longer term 50 day horizon. ${ }^{11}$ A possible

11. A reversal of sign of the gamma coefficient in ASX 1 Gold and ASX 13 Retail as the return measurement intervals lengthen is noted. This is consistent with Chow et al. (1997) who find a reversal of sign in the majority of firms analyzed in their study. Similar findings are also reported by Jorion (1990). 
TABLE 2. Market Model Augmented by an AUDJPY Exchange Rate Factor: Intervaling Results using Overlapping Observations (Daily Based Data)

(1)

\begin{tabular}{|c|c|c|c|c|c|}
\hline \multirow[b]{2}{*}{ Industries } & \multicolumn{5}{|c|}{$\gamma$} \\
\hline & $1-$ day $^{a}$ & $2-\mathrm{day}^{\mathrm{b}}$ & $5-$ day $^{\mathrm{c}}$ & 20-day ${ }^{\mathrm{e}}$ & $50-$ day $^{\mathrm{a}}$ \\
\hline 1. Gold & $.0782^{* *}$ & $.1187 * *$ & $.1602 * *$ & -.0214 & $-.2080 *$ \\
\hline & $(2.16)$ & $(2.44)$ & $(2.48)$ & $(-.23)$ & $(-1.73)$ \\
\hline 2. Other Metals & $.0614^{* *}$ & $.0823^{* *}$ & $.1107 * *$ & $.1198 * *$ & $.3012 * *$ \\
\hline & (3.37) & (3.42) & (3.03) & (2.18) & $(5.66)$ \\
\hline 3. Solid Fuels & .0090 & .0341 & .0391 & $.1309^{* *}$ & $.1269 * *$ \\
\hline & $(.34)$ & (1.19) & $(.99)$ & $(2.67)$ & $(2.23)$ \\
\hline 4. Oil and Gas & -.0131 & -.0025 & -.0068 & -.0097 & -.0041 \\
\hline & $(-.62)$ & $(-.10)$ & $(-.17)$ & $(-.21)$ & $(-.09)$ \\
\hline 5. Diversified & .0060 & .0074 & .0458 & .0062 & -.0253 \\
\hline Resou & $(.27)$ & $(.30)$ & $(1.27)$ & $(.11)$ & $(-.53)$ \\
\hline 6. Developers & $-.0331 *$ & -.0075 & .0285 & .0243 & -.0385 \\
\hline and Contractors & $(-1.74)$ & $(-.37)$ & $(.98)$ & $(.58)$ & $(-.9$ \\
\hline 7. Building & -.0093 & -.0062 & .0100 & .0543 & $.1148 * *$ \\
\hline Materials & $(-.56)$ & $(-.33)$ & $(.37)$ & (1.09) & $(2.27)$ \\
\hline 8. Alcohol & .0055 & -.0009 & -.0214 & .0273 & $.0880^{*}$ \\
\hline and Tobacco & $(.22)$ & $(-.04)$ & $(-.61)$ & $(.60)$ & $(1.69)$ \\
\hline 9. Food and & -.0045 & -.0195 & -.0340 & -.0048 & -.0144 \\
\hline H/hold Goods & $(-.20)$ & $(-.77)$ & $(-.90)$ & $(-.09)$ & $(-.26)$ \\
\hline 10. Chemicals & .0246 & .0350 & .0378 & .0492 & $.1051^{*}$ \\
\hline & $(1.05)$ & $(1.35)$ & $(.98)$ & $(.89)$ & $(1.72)$ \\
\hline 11. Engineering & -.0005 & .0139 & .0371 & $.1319^{* *}$ & $.2454 * *$ \\
\hline & & $(.60)$ & $(1.23)$ & (3.13) & $(6.48)$ \\
\hline 12. Paper & -.0132 & -.0358 & -.0285 & -.0211 & -.0671 \\
\hline and Packaging & $(-.54)$ & $(-1.49)$ & $(-.86)$ & $(-.36)$ & $(-1.51)$ \\
\hline 13. Retail & $-.0397 *$ & $-.0426^{*}$ & -.0327 & -.0033 & $.0836^{*}$ \\
\hline & $(-1.83)$ & $(-1.80)$ & $(-1.12)$ & $(-.07)$ & $(1.88)$ \\
\hline 14. Transport & .0240 & .0092 & .0130 & .0220 & .0236 \\
\hline & $(1.11)$ & $(.32)$ & $(.34)$ & (.43) & $(.50)$ \\
\hline \multirow[t]{2}{*}{ 15. Media } & -.0548 & -.0889 & -.0355 & .0176 & -.2169 \\
\hline & & $(-1.33)$ & $(-.40)$ & & $(-1.48)$ \\
\hline \multirow[t]{2}{*}{ 16. Banks } & -.0012 & -.0276 & -.0302 & -.0300 & -.0034 \\
\hline & $(-.06)$ & $(-1.24)$ & $(-.92)$ & $(-.71)$ & $(-.08)$ \\
\hline
\end{tabular}


TABLE 2. (Continued)

\begin{tabular}{|c|c|c|c|c|c|}
\hline 17. Insurance & $\begin{array}{l}.0148 \\
(.50)\end{array}$ & $\begin{array}{l}.0182 \\
(.46)\end{array}$ & $\begin{array}{l}-.0055 \\
(-.11)\end{array}$ & $\begin{array}{l}-.0884 \\
(-1.53)\end{array}$ & $\begin{array}{l}-.1928 * * \\
(-3.48)\end{array}$ \\
\hline $\begin{array}{l}\text { 18. Entrepreneurial } \\
\text { Investors }\end{array}$ & $\begin{array}{l}.0159 \\
(.37)\end{array}$ & $\begin{array}{l}-.0032 \\
(-.07)\end{array}$ & $\begin{array}{l}-.0316 \\
(-.61)\end{array}$ & $\begin{array}{l}-.0004 \\
(-.01)\end{array}$ & $\begin{array}{l}.1112 \\
(.94)\end{array}$ \\
\hline $\begin{array}{l}\text { 19. Invest. } \\
\text { and Fin. Services }\end{array}$ & $\begin{array}{l}-.0038 \\
(-.29)\end{array}$ & $\begin{array}{l}.0072 \\
(.50)\end{array}$ & $\begin{array}{l}.0154 \\
(.70)\end{array}$ & $\begin{array}{l}.0743 * * \\
(2.16)\end{array}$ & $\begin{array}{l}.1173^{* *} \\
(4.03)\end{array}$ \\
\hline 20. Property Trusts & $\begin{array}{l}-.0175 \\
(-1.29)\end{array}$ & $\begin{array}{l}-.0236 \\
(-1.56)\end{array}$ & $\begin{array}{l}-.0495^{\text {** }} \\
(-2.33)\end{array}$ & $\begin{array}{l}-.1272 * * \\
(-4.29)\end{array}$ & $\begin{array}{l}-.1971 \text { ** } \\
(-8.11)\end{array}$ \\
\hline $\begin{array}{l}\text { 21. Miscellaneous } \\
\text { Services }\end{array}$ & $\begin{array}{l}-.0028 \\
(-.14)\end{array}$ & $\begin{array}{l}-.0279 \\
(-1.32)\end{array}$ & $\begin{array}{c}-.0449 \\
(-1.50)\end{array}$ & $\begin{array}{l}-.0931 * * \\
(-2.12)\end{array}$ & $\begin{array}{l}-.2057 * * \\
(-4.85)\end{array}$ \\
\hline $\begin{array}{l}\text { 22. Miscellaneous } \\
\text { Industrials }\end{array}$ & $\begin{array}{l}.0120 \\
(.53)\end{array}$ & $\begin{array}{l}-.0010 \\
(-.04)\end{array}$ & $\begin{array}{l}.0250 \\
(.64)\end{array}$ & $\begin{array}{l}.1130^{*} \\
(1.88)\end{array}$ & $\begin{array}{l}.1904^{* *} \\
(3.31)\end{array}$ \\
\hline $\begin{array}{l}\text { 23. Diversified } \\
\text { Industrials }\end{array}$ & $\begin{array}{l}-.0114 \\
(-.53)\end{array}$ & $\begin{array}{l}-.0037 \\
(-.17)\end{array}$ & $\begin{array}{l}-.0199 \\
(-.82)\end{array}$ & $\begin{array}{l}.0357 \\
(.88)\end{array}$ & $\begin{array}{l}.1175^{* *} \\
(3.24)\end{array}$ \\
\hline $\begin{array}{l}\text { 24. Tourism and } \\
\text { Leisure }\end{array}$ & $\begin{array}{l}.0012 \\
(.05)\end{array}$ & $\begin{array}{l}.0201 \\
(.74)\end{array}$ & $\begin{array}{l}.0173 \\
(.38)\end{array}$ & $\begin{array}{l}.0499 \\
(.68)\end{array}$ & $\begin{array}{l}.0174 \\
(.22)\end{array}$ \\
\hline
\end{tabular}

Note: **Statistically significant at the $5 \%$ level. *Statistically significant at the $10 \%$

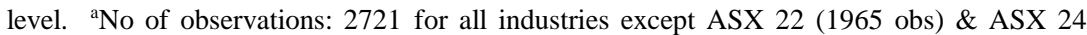
(1052 obs). ${ }^{b}$ No of observations: 2720 for all industries except ASX 22 (1964 obs) \& ASX 24 (1051 obs). ' No of observations: 2717 for all industries except ASX 22 (1961 obs) \& ASX 24 (1048 obs). ${ }^{\mathrm{d}}$ No of observations: 2702 for all industries except ASX 22 (1946 obs) \& ASX 24 (1033 obs). ${ }^{\mathrm{e}}$ No of observations: 2672 for all industries except ASX 22 (1916 obs) \& ASX 24 (1003 obs)

reason for the higher incidence of "long-run" exposure is the volatility in the foreign exchange market, as it is likely to take several days for random fluctuations to net out ${ }^{12}$.

Specifically, when considering the results in table 2, ten (fourteen) industries have statistically significant coefficients at the five (ten) percent level when implementing 50 day horizon returns, while six (seven) industries are significant at the five (ten) percent level when employing 20 day horizon returns. Considerably fewer industries are statistically significant when using shorter horizons. Clearly exchange rate exposure becomes more evident as the horizon lengthens.

Industries ASX 2 Other Metals; ASX 3 Solid Fuels; ASX 11 Engineering; ASX 19 Investment and Financial Services; ASX 20

12. We would like to thank an anonymous referee for suggesting this interpretation. 
Property Trusts; ASX 21 Miscellaneous Services; ASX 22 Miscellaneous Industrials; are all significantly sensitive to the exchange rate factor across both the 20 day and the 50 day horizon. Further, ASX 20 Property Trusts also records a significant coefficient for the 5 day horizon return, while exchange rate exposure is evident for every return horizon for ASX 2 Other Metals. Moreover, the gamma coefficients in all cases except ASX 3 Solid Fuels, increase with an increase in the length of the return horizon. "Short-term" exposure is evident in only four industries, namely ASX 1 Gold; ASX 2 Other Metals; ASX 6 Developers and Contractors; and ASX 13 Retail. ${ }^{13}$

In table 3, which reports the findings of the AUDUSD exchange rate analysis for 1 day, 2 day, 5 day, 20 day and 50 day measurement intervals, similar results to those in table 2 are observed. More specifically, it is observed that exchange rate exposure is generally most significant for long time horizons. Indeed, twelve of the twenty-four industries record a statistically significant exchange rate coefficient when the 50 day horizon return is employed, eleven of which are significant at the five percent level and one being significant at ten percent. Further, of these, six (eight) are also statistically significant at the five (ten) percent level for the 20 day horizon, and, as observed in the AUDJPY analysis, the gamma coefficients generally increase with a lengthening horizon.

As observed in the AUDJPY analysis, there is also some evidence of "short term" exposure in the Australian equities market with respect to the AUSUSD. Consistent with the results reported in table 1, ASX 1 Gold; ASX 2 Other Metals; and ASX 13 Retail are all observed to have one or more statistically significant exchange rate coefficients for the 1 day to 5 day return horizons. However, in this analysis "shortterm" exposure is also observed in ASX 5 Diversified Resources; ASX 8 Alcohol and Tobacco; ASX 12 Paper and Packaging; and ASX 21 Miscellaneous Services.

When comparing table 2 and table 3 , it is noted that the industries which exhibit "long-term" exchange rate exposure (50 day horizon) to both the AUDUSD and the AUDJPY exchange rates are ASX 1 Gold; ASX 2 Other Metals; ASX 7 Building Materials; ASX 10 Chemicals; ASX 11 Engineering; ASX 17 Insurance; ASX 19 Investment and

13. Given the choice of horizon lengths, (i) "short-term" is defined as 1 day, 2 day and 5 day, and (ii) "long-term" is defined as 20 day and 50 day. 
TABLE 3. Market Model Augmented By An AUDUSD Exchange RateFactor Intervaling Results Using Overlapping Observations (Daily Based Data)

\begin{tabular}{|c|c|c|c|c|c|c|}
\hline \multirow{2}{*}{\multicolumn{2}{|c|}{ Industries }} & \multicolumn{5}{|c|}{$\gamma$} \\
\hline & & \multirow{2}{*}{$\frac{1-\mathrm{day}^{\mathrm{a}}}{.025}$} & \multirow{2}{*}{$\frac{2-\mathrm{day}^{\mathrm{b}}}{.2706^{* *}}$} & \multirow{2}{*}{$\frac{5-\text { day }^{\mathrm{c}}}{.3952 * *}$} & \multirow{2}{*}{$\begin{array}{r}20-\text { day }^{\mathrm{e}} \\
.4738^{* *}\end{array}$} & \multirow{2}{*}{$\frac{50-\text { day }^{\mathrm{a}}}{.3340^{*}}$} \\
\hline 1. & Gold & & & & & \\
\hline & & $(-.51)$ & $(-3.68)$ & $(-3.69)$ & $(-2.77)$ & $(-1.78)$ \\
\hline \multirow[t]{2}{*}{2.} & Other Metals & .0493 & $.1411^{* *}$ & $.2682 * *$ & $=.4896 * *$ & $.7228 * *$ \\
\hline & & $(-1.57)$ & $(-3.66)$ & $(-4.56)$ & $(-5.87)$ & $(-7.74)$ \\
\hline \multirow[t]{2}{*}{3.} & Solid Fuels & .0524 & .0468 & .0151 & .0704 & .0045 \\
\hline & & $(-1.32)$ & $(-1.17)$ & $(-.28)$ & $(-.81)$ & $(-.04)$ \\
\hline \multirow[t]{2}{*}{4.} & Oil and Gas & .0075 & .0482 & .0357 & .0968 & .2035 \\
\hline & & $(-.24)$ & $(-1.13)$ & $(-.6)$ & $(-1.33)$ & $(-2.51)$ \\
\hline \multirow[t]{2}{*}{5 . } & Diversified & 0 & $.0909 * *$ & $.1336 * *$ & $.1777 *$ & .1354 \\
\hline & Resources & $(-.01)$ & $(-2.18)$ & $(-2.32)$ & $(-1.75)$ & $(-1.33)$ \\
\hline \multirow[t]{2}{*}{6.} & Developers & -.0429 & -.0246 & -.0275 & .036 & .0018 \\
\hline & and Contractors & $(-1.35)$ & $(-.75)$ & $(-.63)$ & $(-.52)$ & $(-.03)$ \\
\hline \multirow[t]{2}{*}{7.} & Building & -.0165 & -.0133 & -.0015 & .0767 & $.2036 * *$ \\
\hline & Materials & $(-.64)$ & $(-.41)$ & $(-.03)$ & $(-1.08)$ & $(-3.21)$ \\
\hline \multirow[t]{2}{*}{8.} & Alcohol & $.0781^{* *}$ & $.0703^{*}$ & -.001 & -.0718 & -.073 \\
\hline & and Tobacco & $(-2.22)$ & $(-1.69)$ & $(-.01)$ & $(-1.05)$ & $(-.87)$ \\
\hline \multirow[t]{2}{*}{9.} & Food and & -.0268 & .0209 & -.0076 & 0 & -.0514 \\
\hline & H/hold Goods & $(-.67)$ & $(-.45)$ & $(-.11)$ & $(-.00)$ & $(-.54)$ \\
\hline \multirow[t]{2}{*}{10 . } & Chemicals & -.008 & .0017 & .0607 & $.2000 * *$ & $.3518 * *$ \\
\hline & & $(-.24)$ & $(-.04)$ & $(-1.04)$ & $(-2.62)$ & $(-4.28)$ \\
\hline \multirow[t]{2}{*}{11.} & Engineering & -.0407 & .0014 & .0148 & $.3027^{* *}$ & $.5415^{* *}$ \\
\hline & & $(-.88)$ & $(-.04)$ & $(-.34)$ & $(-4.05)$ & $(-7.21)$ \\
\hline \multirow[t]{2}{*}{12.} & Paper and & -.0563 & -.0659 & $-.1147 *$ & -.1024 & -.052 \\
\hline & Packaging & $(-1.39)$ & $(-1.45)$ & $(-1.75)$ & $(-1.40)$ & $(-.54)$ \\
\hline \multirow[t]{2}{*}{13.} & Retail & $-.0574 *$ & -.0253 & -.0029 & .0396 & .0276 \\
\hline & & $(-1.72)$ & $(-.66)$ & $(-.06)$ & $(-.53)$ & $(-.3)$ \\
\hline \multirow[t]{2}{*}{14.} & Transport & -.007 & -.017 & -.0437 & .0029 & -.0439 \\
\hline & & $(-.18)$ & $(-.37)$ & $(-.71)$ & $(-.04)$ & $(-.51)$ \\
\hline \multirow[t]{2}{*}{15.} & Media & .0394 & -.0354 & -.06 & $-.3412 *$ & $-.8906^{* *}$ \\
\hline & & $(-.68)$ & $(-.40)$ & $(-.44)$ & $(-1.77)$ & $(-5.74)$ \\
\hline \multirow[t]{2}{*}{16.} & Banks & -.0161 & -.005 & -.0551 & $-.1206^{*}$ & -.0872 \\
\hline & & $(-.54)$ & $(-.13)$ & $(-1.08)$ & $(-1.84)$ & $(-1.29)$ \\
\hline
\end{tabular}


TABLE 3: (Continued)

\begin{tabular}{|c|c|c|c|c|c|}
\hline 17. Insurance & $\begin{array}{l}.0264 \\
(-.56)\end{array}$ & $\begin{array}{l}.0443 \\
(-.77)\end{array}$ & $\begin{array}{l}.0301 \\
(-.38)\end{array}$ & $\begin{array}{l}-.0975 \\
(-1.03)\end{array}$ & $\begin{array}{l}-.4780^{* *} \\
(-4.13)\end{array}$ \\
\hline $\begin{array}{l}\text { 18. Entrepreneurial } \\
\text { Investors }\end{array}$ & $\begin{array}{l}0 \\
(-.01)\end{array}$ & $\begin{array}{l}-.0618 \\
(-1.22)\end{array}$ & $\begin{array}{l}-.1395^{*} \\
(-1.86)\end{array}$ & $\begin{array}{l}-.2429 * \\
(-1.94)\end{array}$ & $\begin{array}{l}-.0749 \\
(-.48)\end{array}$ \\
\hline $\begin{array}{l}\text { 19. Invest. } \\
\text { and Fin. Services }\end{array}$ & $\begin{array}{l}.0019 \\
(-.08)\end{array}$ & $\begin{array}{l}.0166 \\
(-.69)\end{array}$ & $\begin{array}{r}.0489 \\
(-1.49)\end{array}$ & $\begin{array}{l}.1510^{* * *} \\
(-3.17)\end{array}$ & $\begin{array}{l}.3145^{* *} \\
(-5.67)\end{array}$ \\
\hline 20. Property Trusts & $\begin{array}{l}-.0279 \\
(-1.25)\end{array}$ & $\begin{array}{l}-.0146 \\
(-.64)\end{array}$ & $\begin{array}{l}-.0325 \\
(-.97)\end{array}$ & $\begin{array}{l}-.0883^{*} \\
(-1.84)\end{array}$ & $\begin{array}{l}-.1599 * * \\
(-3.56)\end{array}$ \\
\hline $\begin{array}{l}\text { 21. Miscellaneous } \\
\text { Services }\end{array}$ & $\begin{array}{l}-.0257 \\
(-1.01)\end{array}$ & $\begin{array}{l}-.0627 * \\
(-1.94)\end{array}$ & $\begin{array}{l}-.1117^{* *} \\
(-2.47)\end{array}$ & $\begin{array}{l}-.2731 * * \\
(-3.74)\end{array}$ & $\begin{array}{l}-.4994 * * \\
(-7.53)\end{array}$ \\
\hline $\begin{array}{l}\text { 22. Miscellaneous } \\
\text { Industrials }\end{array}$ & $\begin{array}{r}-.049 \\
(-1.11)\end{array}$ & $\begin{array}{l}.0116 \\
(-.2)\end{array}$ & $\begin{array}{l}.1212 \\
(-1.41)\end{array}$ & $\begin{array}{l}.2339^{* *} \\
(-2.12)\end{array}$ & $\begin{array}{l}.1455 \\
(-1.5)\end{array}$ \\
\hline $\begin{array}{l}\text { 23. Diversified } \\
\text { Industrials }\end{array}$ & $\begin{array}{l}.0196 \\
(-.55)\end{array}$ & $\begin{array}{r}.031 \\
(-.88)\end{array}$ & $\begin{array}{l}.0263 \\
(-.68)\end{array}$ & $\begin{array}{l}.0464 \\
(-.88)\end{array}$ & $\begin{array}{l}.1413^{* *} \\
(-2.61)\end{array}$ \\
\hline $\begin{array}{l}\text { 24. Tourism and } \\
\text { Leisure }\end{array}$ & $\begin{array}{l}-.0166 \\
(-.36)\end{array}$ & $\begin{array}{l}.0177 \\
(-.33)\end{array}$ & $\begin{array}{l}.0061 \\
(-.09)\end{array}$ & $\begin{array}{l}.1367 \\
(-1.51)\end{array}$ & $\begin{array}{l}.4832 * * \\
(-4.4)\end{array}$ \\
\hline
\end{tabular}

Note: ** Statistically significant at the 5\% level. *Statistically significant at the $10 \%$

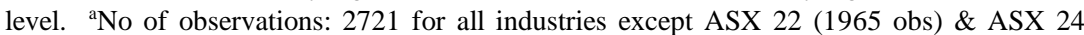
(1052 obs). ${ }^{b}$ No of observations: 2720 for all industries except ASX 22 (1964 obs) \& ASX 24 (1051 obs). ' No of observations: 2717 for all industries except ASX 22 (1961 obs) \& ASX 24 (1048 obs). ${ }^{\mathrm{d}}$ No of observations: 2702 for all industries except ASX 22 (1946 obs) \& ASX 24 (1033 obs). ${ }^{\mathrm{e}}$ No of observations: 2672 for all industries except ASX 22 (1916 obs) \& ASX 24 (1003 obs)

Financial Services; ASX 20 Property Trusts; ASX 21 Miscellaneous Services and ASX 23 Diversified Industrials. However, Media (ASX 15); and Tourism and Leisure (ASX 24); are only statistically significant in response to the AUDUSD while Alcohol and Tobacco (ASX 8); Retail (ASX 13); and Miscellaneous Industrials (ASX 22) only exhibit "long-term" exchange rate exposure to the AUDJPY exchange rate. Further, although ASX 5 Diversified Resources and ASX 18 Entrepreneurial Investors do not exhibit exchange rate exposure to the AUDJPY, there is some evidence of exchange rate exposure to the AUDUSD. Specifically, the results reported in table 3 indicate that although neither industry portfolio is statistically significant for the 50 day return horizon, both exhibit persistent exchange rate exposure across the 5-day and 20-day return horizons, while the ASX 5 Diversified Resources is also statistically significant for the 2-day horizon.

In a bid to test the robustness of the results, some analysis using non- 
overlapping observations was undertaken. ${ }^{14}$ Specifically, the overlapping results for the 50-day interval case were compared to the nonoverlapping results for the same interval case. The findings are as follows:

(i) the number of statistically significant coefficients resulting from the overlapping analysis was considerably higher than those observed in the non-overlapping investigation; ${ }^{15}$

(ii) when comparing the sign of the exposure across the two analyzes, it is found that the non-overlapping subset of statistically significant coefficients are of the same sign as those observed in the overlapping investigation, that is the same directional exposure is observed;

(iii) the magnitude and sign of the estimated gamma coefficients is consistent across the two analyzes ${ }^{16}$ and

(iv) in comparing the sign of the exposure across the two exchange rate factors, the same directional exposure is observed. These consistencies support the analysis and implementation of an overlapping return interval approach.

\section{Foreign Exchange Exposure - Overlapping Analysis Employing Monthly Base Data}

Table 4 reports the results for the investigation of 1 month, 3 month, 6 month, 12 month, 24 month, 36 month and 48 month measurement intervals using the AUDJPY. Of the seven return horizons analyzed, the highest incidence of significant exchange rate coefficients is reported for the thirty-six month horizon in which twenty-one (twenty-two) industries are statistically significant at the five (ten) percent level. In addition,

14. Details of this analysis are not reported in order to conserve space.

15. Specifically, for the AUDJPY (AUDUSD) analysis, four (six) statistically significant coefficients for the non-overlapping time periods and thirteen (twelve) statistically significant coefficients for the overlapping time periods are observed.

16. For example, in the AUDJPY analysis-ASX 2: .3012 (overlapping) and .3491 (non-overlapping); ASX 11: .2454 (overlapping) and .2123 (non-overlapping); ASX 21: -.2673 (overlapping) and -.2673 (non-overlapping). Similarly, when employing the AUDUSD exchange rate factor- ASX 2: .7228 (overlapping) and .8754 (non-overlapping); ASX 11: .5415 (overlapping) and .5408 (non-overlapping) and ASX 21: -.1599 (overlapping) and -.1994 (non-overlapping). 


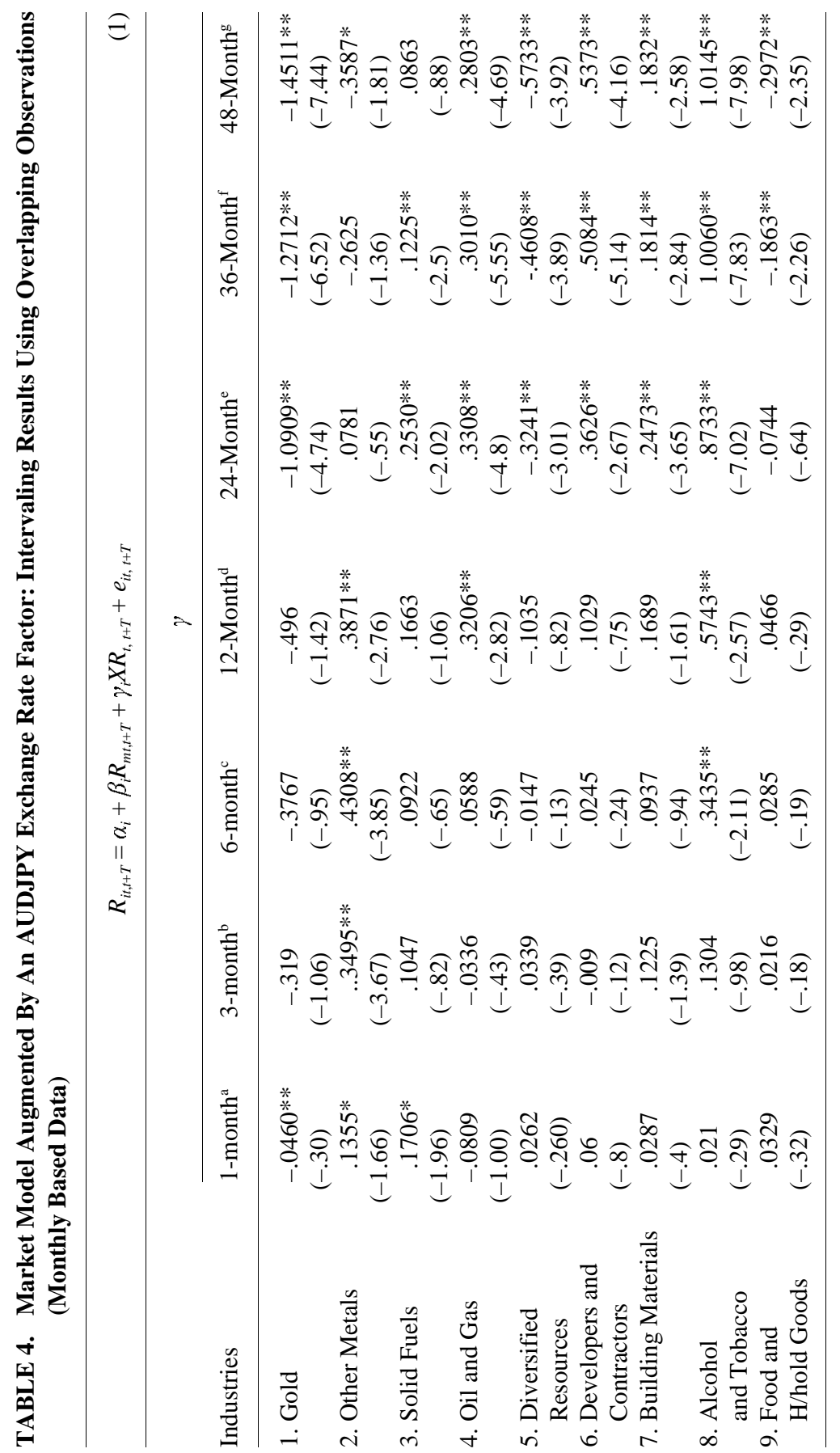




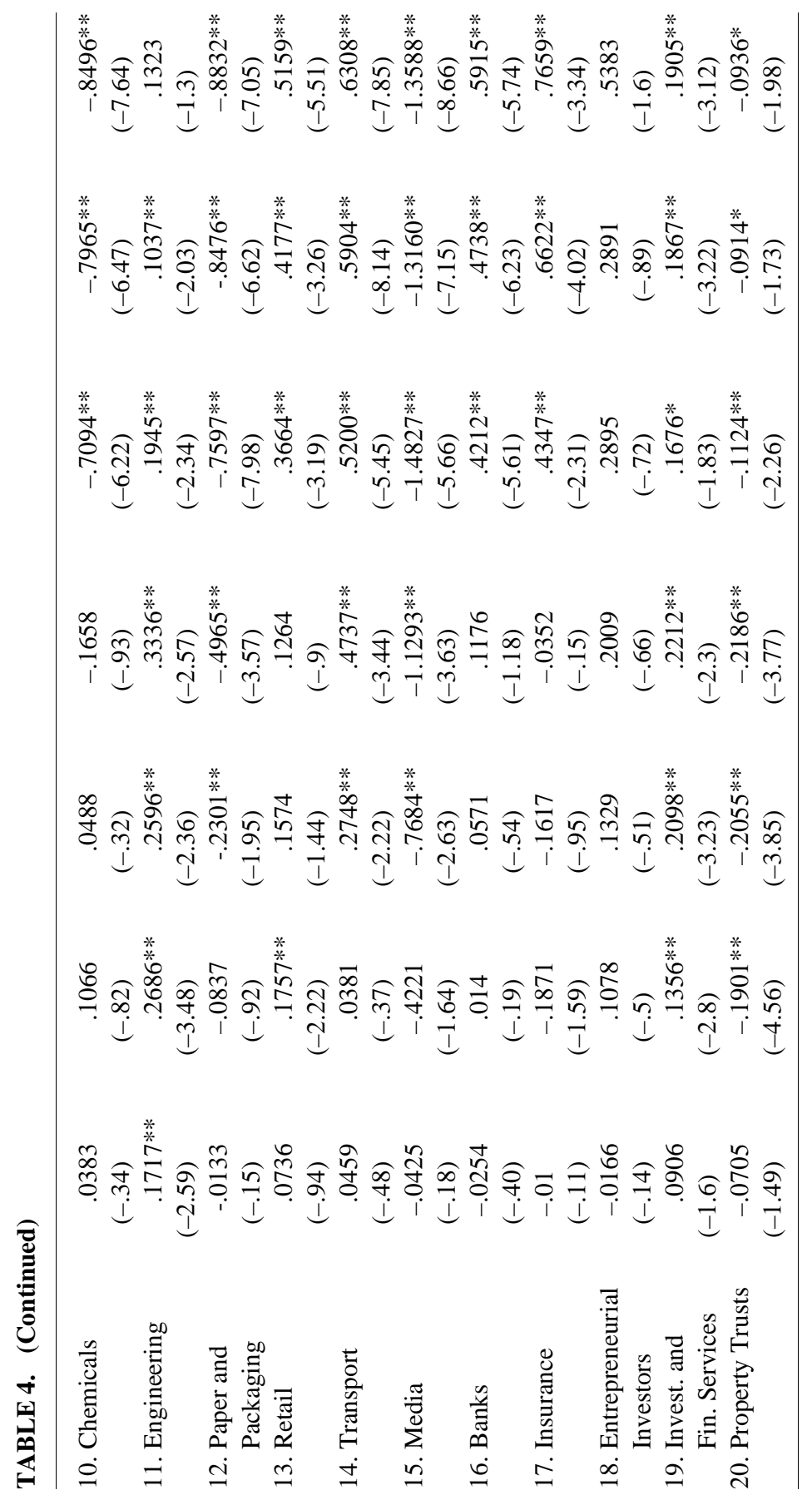




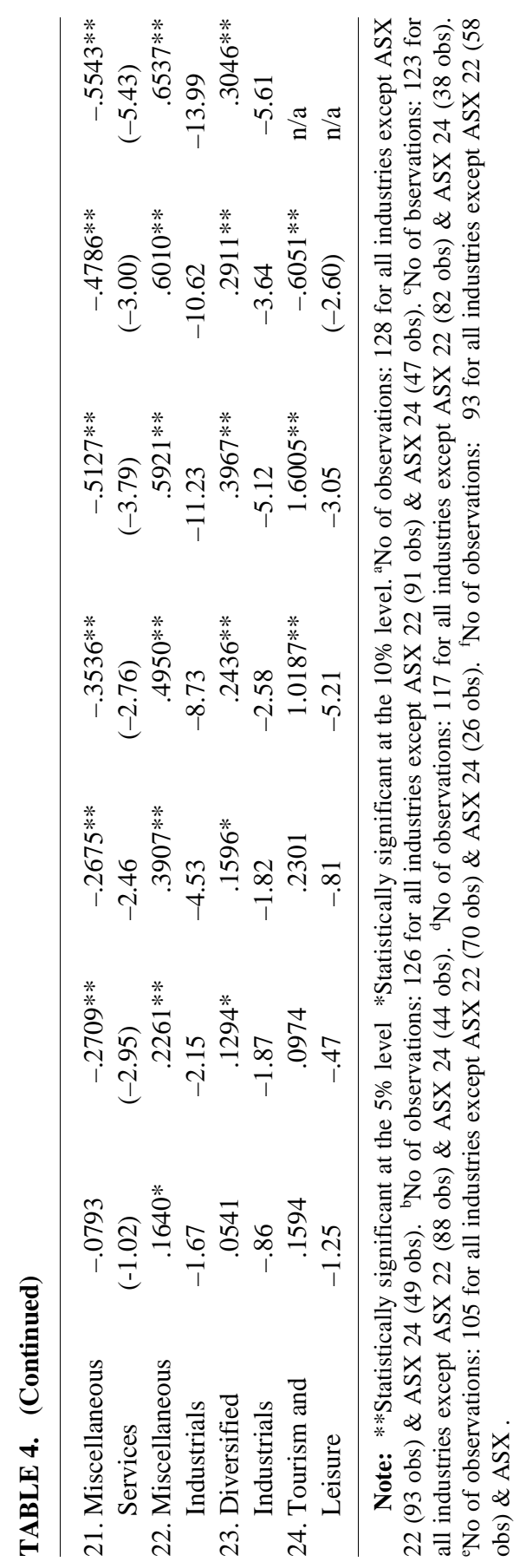


twenty (twenty-one) and eighteen (twenty) industries are observed to be statistically significant at the five (ten) percent level for the twentyfour and forty-eight month measurement intervals respectively. ${ }^{17}$ Further, sixteen (eighteen) of the twenty-four industries are statistically sensitive at the five (ten) percent level across the three "long-term" return horizons. The only industries that do not exhibit statistically significant "long-term" exposure over the twenty-four, thirty-six, and forty-eight month measurement intervals are ASX 2 Other Metals; ASX 3 Solid Fuels; ASX 9 Food and Household Goods; ASX 11 Engineering; ASX 18 Entrepreneurial Investors; ASX 24 Tourism and Leisure. In addition, thirteen industries record significant exchange rate exposure for the twelve-month measurement interval, eleven for the six-month horizon, eight for the three-month horizon and five for the one-month horizon. Of the large number of statistically significant coefficients across these four return horizons, all but five are significant at the five percent level.

Based on these results, the findings of the earlier analysis that most industries experience "long-term" exchange rate exposure, are generally confirmed. Of note are several industries that exhibit statistically significant exposure for measurement intervals less than, as well as greater than, twelve months. Specifically, statistically significant exposure is observed at the ten percent level from the three month to the forty-eight month measurement interval for ASX 19 Investment and Financial Services; ASX 20 Property Trusts; ASX 21 Miscellaneous Services; ASX 22 Miscellaneous Industrials; and ASX 23 Diversified Industrials. Indeed, ASX 22 Miscellaneous Industrials, exhibits statistically significant exposure at the 10 percent level for each of the seven measurement intervals. Further, it is observed that there is a general increase (in magnitude) in the exchange rate coefficient in many cases, for example, ASX 1 Gold; ASX 6 Developers and Contractors; ASX 8 Alcohol and Tobacco; ASX 12 Paper and Packaging; ASX 14 Transport; ASX 16 Banks; ASX 21 Miscellaneous Services; and ASX 22 Miscellaneous Industrials. ${ }^{18}$

17. It should be noted that due to the lack of sufficient data for ASX 24 Tourism and Leisure, an analysis of this industry using a 36 and a 48 month return horizon was not possible.

18. A reversal of sign of the gamma coefficient in ASX 2 Other Metals and ASX 24 
Table 5 reports the counterpart analysis employing the AUDUSD exchange rate. These results are similar to those observed in table 4 for the one, three, six and twelve month return horizons with a similar number of significant coefficients reported for each horizon. Further, for these return horizons several industries appear to experience significant exchange rate exposure relative to both exchange rates, for example, ASX 2 Other Metals; ASX 11 Engineering; ASX 15 Media; ASX 19 Investment and Financial Services; ASX 20 Property Trusts; ASX 21 Miscellaneous Services; and ASX 22 Diversified Industrials. For horizons longer than twelve months, exchange rate exposure to the AUDUSD appears significantly weaker than that experienced by Australian industries to the AUDJPY. This is evidenced by a notable decrease in the number of significant coefficients for the twenty-four, thirty-six and forty-eight month horizons in the AUDUSD analysis. Specifically, there are nine (eleven) coefficients significant at the five (ten) percent level for the twenty-four month horizon, nine (eleven) are significant at the five (ten) percent level for the thirty-six month horizon and seven (eight) coefficients are significant at the five (ten) percent level for the forty-eight month horizon. Thus, when employing the AUDUSD the highest incidence of significant coefficients occurs in the twelve-month return horizon.

Industries that appear to be exposed to both exchange rates for longterm horizons are ASX 4 Oil and Gas; ASX 7 Building Materials; ASX 15 Media; ASX 20 Property Trusts; ASX 21 Miscellaneous Services; and ASX 24 Tourism and Leisure. Generally, however, it would appear that although the results of the analysis suggest that the Australian equities market experiences "long-term" exchange rate exposure, it is considerably less exposed to the AUDUSD exchange rate than to the AUDJPY exchange rate.

\section{Discussion and Correlation Analysis}

In summary, the results of this analysis appear to suggest that generally the Australian equities market is exposed to "long-term", or economic, exchange rate exposure. Where "short-term" exposure seems to be

Tourism and Leisure as the return measurement intervals lengthen is noted. Again, (see Footnote 11), this is consistent with Chow et al. (1997) who find a reversal of sign in the majority of firms analyzed in their study. 


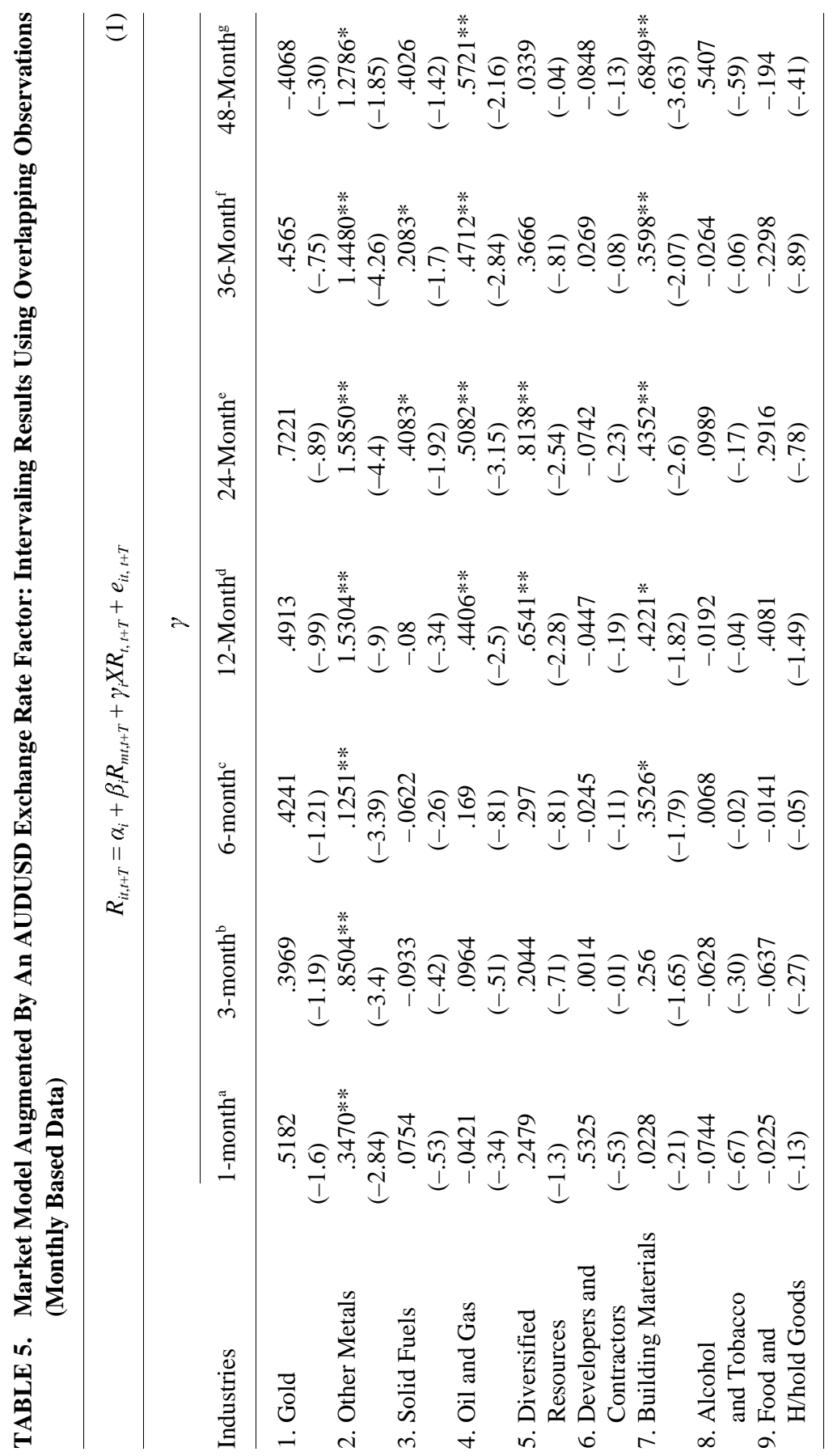




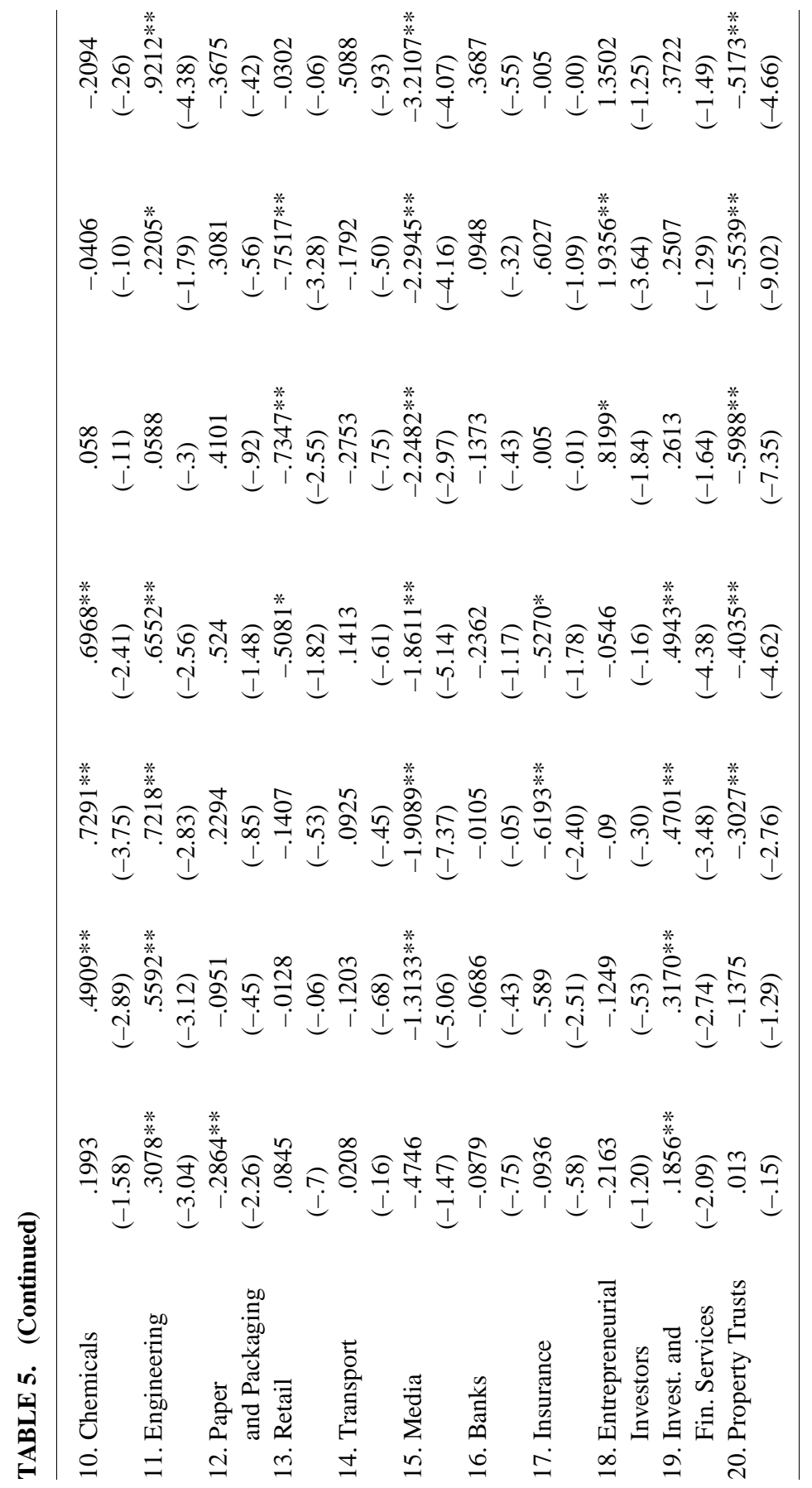




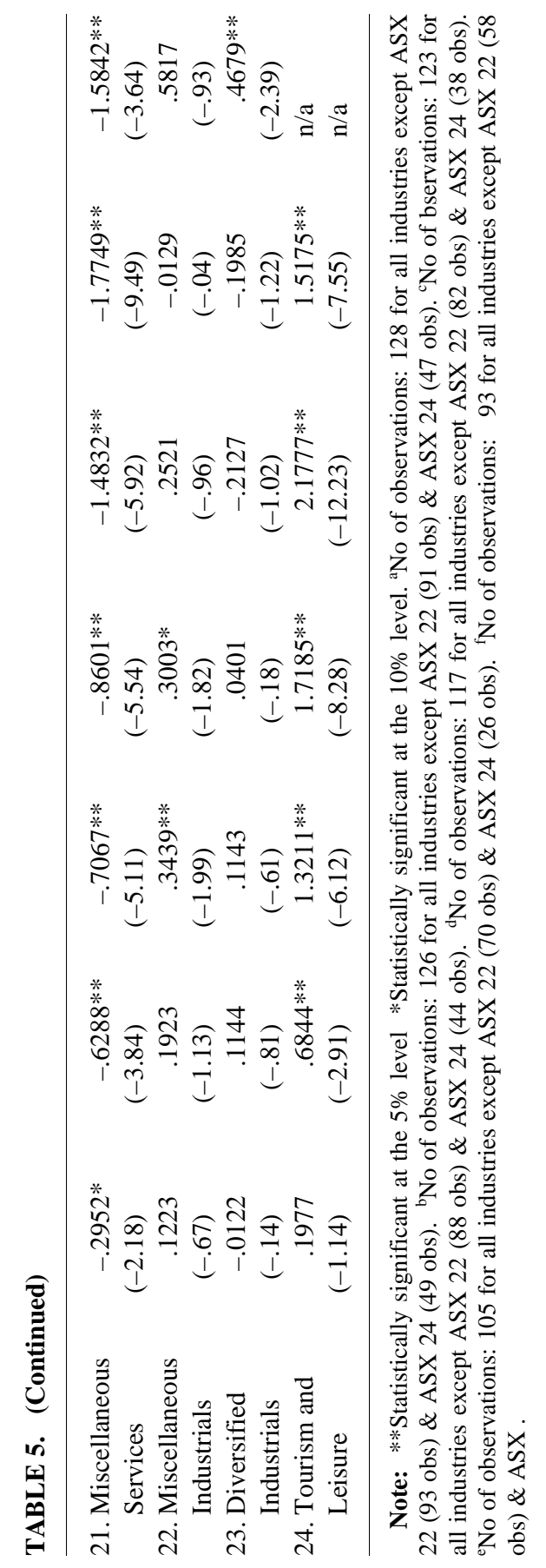


relatively well hedged by most Australian industries, significant "longterm" exposure is observed across the Australian equities market. These findings support those of Chow et al. (1997 a, b), who suggest that ignorance of this intervaling effect may indeed explain the lack of empirical evidence in this area of research. Further, the findings of the current study suggest that Australian shareholder returns are more exposed in the longer term to fluctuations in the Australian dollar/Japanese yen exchange rate than they are to the Australian dollar/US dollar exchange rate. This is particularly evident in the monthly 'base' data analysis. Although Japan is Australia's largest trading partner, since a major proportion of Australian foreign trade contracts are written against the US dollar, Australian companies are most likely to hedge against possible movements in the AUDUSD. ${ }^{19}$ As such, this is consistent with Australian companies successfully managing their transaction exposure.

Further, the results highlight the importance of movements in the AUDJPY to the Australian shareholder. It would seem that although many firms trade with Japan and would therefore to some extent hedge their exchange rate risk, Australian firms in general are exposed to fluctuations in the AUDJPY. This should not be surprising given the strength of the Japanese economy in the Asian region. However, it appears from these results that either Australian financial managers ignore this exposure in their risk management decision-making process or that it represents an economic exposure that is unrelated to known transactions, and hence is very difficult to manage. The latter explanation is more likely to be true.

Table 6 reports the correlation coefficients between the exchange rate exposure gammas of different return horizons using daily data. The results indicate a strong positive correlation between the estimated exchange exposures across horizons for the daily data analysis. However, the correlation is stronger between any two horizons for the AUDJPY exchange rate (Panel A) than for the AUDUSD exchange rate (Panel B). For the AUDJPY exchange rate, the correlation between the one-day exchange rate exposure and other horizons declines as the horizon length increases. Such is also the case for the

19. Possible future research in this area is an investigation of the firms in those industries observed to be exposed to movements in the AUDUSD. This is beyond the scope of the current study. 
TABLE 6. Correlation Coefficients Between Exposure Gammas Of Different Return Horizons Using Daily Based Data (1988 to 1998)

Horizon 2-Day 20-Day 5-Day

A. AUDJPY Exchange Rate Exposure

2 Day $\quad .9067$

5 Day $\quad .7587$

20 Day $\quad .1836$

.4614

50 Day

.2011

.2613

.2407

.8313

B. AUDUSD Exchange Rate Exposure

2 Day

5 Day

20 Day

50 Day

.3417

.1238

.0696

.1093
.4677

.4128

.3583
.4068

.3716
.2933

two-day horizon. The highest correlation coefficient (.9067) is recorded between the 1 and 2 day horizon for the AUDJPY exchange rate. A similar pattern emerges for the analysis of the correlation of the exposure for the AUDUSD exchange rate.

The counterpart correlation coefficients between different horizon gammas for the monthly based data are reported in table 7. Again a strong positive correlation between the exposure recorded for the various horizons for both exchange rates is noted. However, as discussed above, there is a declining correlation between exposures the more disparate is the horizon. For the AUDJPY exchange rate (Panel A), the highest correlation (.9669) occurs between the thirty-six and forty-eight month horizons. The lowest correlation (.4277) is between the exposure of the one-month horizon and the thirty-six month horizon. When considering the AUDUSD exchange rate in Panel B, similar results are evident. The highest correlation (.9249) is noted between the thirty-six and forty-eight month horizons, while the lowest correlation coefficient (.2066) is recorded between one month and forty-eight months. These results are consistent with those of Chow et al (1997 a, b) who also find a strong, positive correlation between the estimated exchange exposures across horizons and that correlation diminishes as the difference between any two horizons increases. 
TABLE 7. Correlation Coefficients Between Exposure Gammas of Different Return Horizons Using Monthly Based Data (1988 to 1998)

\begin{tabular}{|c|c|c|c|c|c|c|}
\hline Horizon & 1-Month & 3-Month & 6-Month & 12-Month & 24-Month & 36-Month \\
\hline \multicolumn{7}{|c|}{ A. AUDJPY Exchange Rate Exposure } \\
\hline 3 Month & .7560 & & & & & \\
\hline 6 Month & .6688 & .9312 & & & & \\
\hline 12 Month & .6039 & .7625 & .9078 & & & \\
\hline 24 Month & .4890 & .6039 & .7692 & .9346 & & \\
\hline 36 Month & .4273 & .7173 & .8651 & .9282 & .9157 & \\
\hline 48 Month & .4941 & .7724 & .8966 & .9409 & .9214 & .9669 \\
\hline \multicolumn{7}{|c|}{ B. AUDUSD Exchange Rate Exposure } \\
\hline 3 Month & .7552 & & & & & \\
\hline 6 Month & .6294 & .9075 & & & & \\
\hline 12 Month & .6135 & .9245 & .8914 & & & \\
\hline 24 Month & .5263 & .7968 & .7835 & .9073 & & \\
\hline 36 Month & .3068 & .4843 & .5034 & .4985 & .7378 & \\
\hline 48 Month & .2066 & .3987 & .4235 & .3487 & .5937 & .9249 \\
\hline
\end{tabular}

\section{E. Cross-Sectional Analysis}

As discussed in Section 2.2, the current study investigates whether the analysis of a number of industry characteristics sheds some light on the determinants of foreign exchange exposure. Although dummy variables are implemented to identify non-traded goods and producers of complementary imports, continuous data for competing imports, exports and internationally-priced inputs is used. Table 8 reports a summary of the relative Competing Import Input-Output coefficient, the relative Export Input-Output coefficient and the relative Petroleum and Coal Products coefficient (as a proxy for internationally-priced inputs) for the twenty-four industry portfolios of the Australian Stock Exchange. Based on simple economic theory, a positive sign would be predicted for complementary imports, competing imports and non-traded goods and users of internationally priced inputs, while a negative sign would be expected for exports.

Table 9 reports the results of estimating the cross-sectional equation given by (2') in which the variables of imports, exports and the industry 
TABLE 8. Relative Input-Output Export And Import Measures Across Australian Industry Classifications

\begin{tabular}{|c|c|c|c|}
\hline ASX Industry Classification & $\begin{array}{l}\text { Relative Export } \\
\text { Coefficient }\end{array}$ & $\begin{array}{l}\text { Relative } \\
\text { Competing } \\
\text { Imports } \\
\text { Coefficient }\end{array}$ & $\begin{array}{l}\text { Relative Petroleum } \\
\text { and Coal Products } \\
\text { Coefficient }\end{array}$ \\
\hline 1 Gold & 4.07146 & 0.61691 & 1.81180 \\
\hline 2 Other Metals & 4.06439 & 0.97104 & 1.90885 \\
\hline 3 Solid Fuels & 1.02993 & 4.23906 & 2.16580 \\
\hline 4 Oil \& Gas & 1.02993 & 4.23906 & 2.16580 \\
\hline 5 Diversified Resources & 2.62967 & 0.75143 & 1.02080 \\
\hline 6 Developers \& Contractors & 0.00007 & 0.63285 & 0.45070 \\
\hline 7 Building Materials & 3.27971 & 1.07136 & 0.65850 \\
\hline 8 Alcohol \& Tobacco & 0.31713 & 0.65854 & 0.57100 \\
\hline 9 Food \& Household Goods & 1.13878 & 0.65247 & 0.85230 \\
\hline 10 Chemicals & 1.60483 & 2.17983 & 1.31240 \\
\hline 11 Engineering & 0.85959 & 1.79175 & 0.18645 \\
\hline 12 Paper \& Packaging & 0.76023 & 1.46254 & 2.39013 \\
\hline 13 Retail & 0.30830 & 1.42499 & 0.28460 \\
\hline 14 Transport & 1.71640 & 0.67186 & 4.98910 \\
\hline 15 Media & 0.65594 & 1.08379 & 0.64990 \\
\hline 16 Banks & 0.18568 & 0.17257 & 0.08100 \\
\hline 17 Insurance & 0.18568 & 0.17257 & 0.08100 \\
\hline 18 Entrepreneurial Investors & 0.31713 & 0.65854 & 0.57100 \\
\hline 19 Investment \& Finance ${ }^{\mathrm{d}}$ & na & na & na \\
\hline 20 Property Trusts & 0.78703 & 0.38000 & 0.76990 \\
\hline 21 Miscellaneous Services & 0.00002 & 0.48216 & 1.15705 \\
\hline 22 Miscellaneous Industrials & 1.79849 & 0.79184 & 0.95340 \\
\hline 23 Diversified Industrials & 3.27971 & 1.07136 & 0.65850 \\
\hline 24 Tourism \& Leisure & 0.00014 & 0.63303 & 0.21245 \\
\hline
\end{tabular}

Note: ${ }^{\text {a } R e l a t i v e ~ M e a s u r e ~ f o r ~ e a c h ~ i n d u s t r y ~ i s ~ c a l c u l a t e d ~ a s ~ t h e ~ r a t i o ~(I n p u t-O u t p u t ~ E x p o r t ~}$ Co-efficient) / (Aust. Industry Average Export Input-Output Co-efficient). ' ${ }^{b}$ Relative Measure for each industry is calculated as the ratio (Input-Output Competing Import Coefficient) / (Aust. Industry Average Competing Import Input-Output Co-efficient). 'Relative Measure for each industry is calculated as the ratio (Input-Output Petroleum and Coal Coefficient) / (Aust. Industry Average Petroleum and Coal Input-Output Co-efficient). dSince ASX 19 could not be matched with an ABS classification, the Input-Output coefficients for this industry was not able to be calculated. 
TABLE 9. Cross-Sectional Analysis: Regression of Exchange Rate Gamma On Relative Import Coefficient and Relative Export Coefficient - Daily Based Data (1988 to 1998)

\begin{tabular}{|c|c|c|c|}
\hline & $\begin{array}{l}\text { Relative Import } \\
\text { Coefficient (RIC) } \\
\text { ( } t \text {-statistic) }\end{array}$ & $\begin{array}{l}\text { Relative Export } \\
\text { Coefficient (REC) } \\
\text { ( } t \text {-statistic) }\end{array}$ & $\begin{array}{c}\beta \\
(t \text {-statistic })\end{array}$ \\
\hline \multicolumn{4}{|c|}{ A. AUDJPY Exchange Rate Exposure } \\
\hline 1 Day & $\begin{array}{l}-0.0033 \\
(-0.54)\end{array}$ & $\begin{array}{l}0.0134 * * \\
(2.78)\end{array}$ & $\begin{array}{l}-0.0073 \\
(-0.20)\end{array}$ \\
\hline 2 Day & $\begin{array}{l}0.0016 \\
(0.18)\end{array}$ & $\begin{array}{l}0.0201 * * \\
(3.06)\end{array}$ & $\begin{array}{l}-0.0155 \\
(-0.31)\end{array}$ \\
\hline 5 Day & $\begin{array}{l}0.0099 \\
(1.11)\end{array}$ & $\begin{array}{l}0.0227 * * \\
(3.22)\end{array}$ & $\begin{array}{l}0.0596 \\
(1.15)\end{array}$ \\
\hline 20 Day & $\begin{array}{l}0.0330 * * \\
(2.65)\end{array}$ & $\begin{array}{l}0.0095 \\
(0.91)\end{array}$ & $\begin{array}{l}0.1205 \\
(1.70)\end{array}$ \\
\hline 50 Day & $\begin{array}{l}0.0404 \\
(1.35)\end{array}$ & $\begin{array}{l}0.0299 \\
(1.18)\end{array}$ & $\begin{array}{l}0.0289 \\
(0.17)\end{array}$ \\
\hline \multicolumn{4}{|c|}{ B. AUDUSD Exchange Rate Exposure } \\
\hline 1 Day & $\begin{array}{l}0.0091 \\
(1.03)\end{array}$ & $\begin{array}{l}0.0051 \\
(0.72)\end{array}$ & $\begin{array}{l}0.0378 \\
(0.70)\end{array}$ \\
\hline 2 Day & $\begin{array}{l}-0.0031 \\
(-0.21)\end{array}$ & $\begin{array}{l}0.0401 * * \\
(3.65)\end{array}$ & $\begin{array}{l}-0.0543 \\
(-0.04)\end{array}$ \\
\hline 5 Day & $\begin{array}{l}-0.0013 \\
(-0.06)\end{array}$ & $\begin{array}{l}0.0699 * * \\
(4.57)\end{array}$ & $\begin{array}{l}-0.0205 \\
(-0.18)\end{array}$ \\
\hline 20 Day & $\begin{array}{l}0.0317 \\
(0.91)\end{array}$ & $\begin{array}{l}0.1108 * * \\
(3.92)\end{array}$ & $\begin{array}{l}-0.0208 \\
(-0.11)\end{array}$ \\
\hline 50 Day & $\begin{array}{l}0.0533 \\
(0.83)\end{array}$ & $\begin{array}{l}0.1459 * * \\
(2.76)\end{array}$ & $\begin{array}{l}-0.2569 \\
(-0.74)\end{array}$ \\
\hline
\end{tabular}

Note: **Statistically significant at the $5 \%$ level. * Statistically significant at the $10 \%$ level. The number of observations in each case was 23 . 
TABLE 10. Cross-Sectional Analysis: Regression of Exchange Rate Gamma On Relative Import Coefficient And Relative Export Coefficient Monthly Based Data (1988 to 1998)

\begin{tabular}{|c|c|c|}
\hline \multicolumn{3}{|c|}{$\gamma_{i}=C_{1}+\underset{(+)}{C_{2}} R I C_{i}+\underset{(-)}{C_{2}} R E C_{i}+C_{3} \beta_{i}+e_{i}$} \\
\hline Relative Import & Relative Export & \\
\hline $\begin{array}{l}\text { Coefficient (RIC) } \\
(t \text {-statistic) }\end{array}$ & $\begin{array}{l}\text { Coefficient (REC) } \\
(t \text {-statistic) }\end{array}$ & $\begin{array}{c}\beta \\
(t \text {-statistic })\end{array}$ \\
\hline
\end{tabular}

A. AUDJPY Exchange Rate Exposure

$\begin{array}{cccc}1 \text { Month } & 0.0203 & 0.0013 & 0.0949 \\ & (1.13) & (0.09) & (0.94) \\ 3 \text { Month } & 0.0274 & 0.0322 & -0.0778 \\ & (0.68) & (0.95) & (-0.37) \\ 6 \text { Month } & 0.0102 & 0.0373 & -0.3339 \\ & (0.19) & (0.81) & (-1.38) \\ 12 \text { Month } & 0.0104 & -0.0126 & -0.3643 \\ & (0.12) & (-0.17) & (-1.27) \\ 24 \text { Month } & -0.0443 & -0.1589 & -0.3280^{* *} \\ & (-0.36) & (-1.54) & (-2.13) \\ 36 \text { Month } & 0.0056 & 0.0357 & -0.3828^{* *} \\ & (0.05) & (0.36) & (-2.16) \\ 48 \text { Month } & 0.0206 & 0.0087 & -0.2916^{*} \\ & (0.19) & (0.09) & (-1.86)\end{array}$

B. AUDUSD Exchange Rate Exposure

\begin{tabular}{lccc}
1 Month & 0.0044 & $0.0792 *$ & 0.0340 \\
& $(0.08)$ & $(1.86)$ & $(0.12)$ \\
3 Month & 0.0259 & $0.1775^{* *}$ & -0.3954 \\
& $(0.30)$ & $(2.54)$ & $(-0.88)$ \\
6 Month & 0.0551 & 0.1309 & -0.4315 \\
& $(0.45)$ & $(1.27)$ & $(-0.77)$ \\
12 Month & 0.0536 & $0.2424 * *$ & -0.6502 \\
& $(0.39)$ & $(2.15)$ & $(-1.48)$ \\
24 Month & 0.0529 & 0.2047 & -0.1971 \\
& $(0.30)$ & $(1.38)$ & $(-0.89)$ \\
& & & \\
\hline
\end{tabular}


TABLE 10. (Continued)

\begin{tabular}{lllc}
\hline 36 Month & -0.0214 & 0.0636 & 0.0288 \\
& $(-0.08)$ & $(0.30)$ & $(0.08)$ \\
48 Month & -0.0147 & -0.0010 & -0.2967 \\
& $(-0.05)$ & $(-0.00)$ & $(-0.77)$ \\
\hline
\end{tabular}

Note: ** Statistically significant at the $5 \%$ level. * Statistically significant at the $10 \%$ level. The number of observations in each case was 23 .

beta are examined. ${ }^{20}$ Specifically, in this case the exchange rate exposures generated from overlapping daily 'base' data for both the AUDJPY exchange rate (Panel A) and the AUDUSD exchange rate (Panel B) are used as the dependent variable. The results indicate that for the former, exports are statistically significant in the "short term" (1 to 5 days), while imports become significant when the 20-day horizon return is employed. However, it is observed that exports alone are significant for the AUDUSD exchange rate analysis. This is evident for all horizons except the 1-day case. However, the results are difficult to interpret given that they are generally contrary to the predicted impact of an appreciation in the Australian dollar. Specifically, although the statistically significant import coefficient in Panel A is positive as expected, not one export coefficient in the analysis is negative.

Table 10, which contains the counterpart cross-sectional analysis using exchange rate exposures generated from longer horizons of monthly overlapped data, reports similarly discouraging results. Using monthly 'base' data appears to result in very little evidence of a relationship between exchange rate exposure and industry characteristics, regardless of the exchange rate employed.

\section{Summary}

20. The results of the cross-sectional equation given by (2) are unreported due to the lack of significant findings. They are available from the authors upon request. 
This study investigates the impact of foreign exchange exposure on the Australian equities market. Specifically, using the twenty-four industry portfolios as classified by the Australian Stock Exchange, an analysis of the impact of movements in the Australian Dollar to the Japanese Yen (AUDJPY) and the Australian Dollar to the US Dollar (AUDUSD) exchange rates on shareholder returns over increasing return measurement intervals is undertaken. Specifically, both daily 'base' data and monthly 'base' data are employed to generate sets of overlapping observations of longer horizon data.

The results indicate that the exchange rate exposure of the Australian equities market is essentially "long-term". These findings are consistent with the suggestion that although Australian firms manage their short-term exposure, they do not successfully hedge long term, or economic exposure, supporting Chow, Lee and Solt's (1997 a, b) findings. Further, it appears that the Australian market as a whole is significantly exposed to fluctuations in the AUDJPY, while only some industries are exposed to movements in the AUDUSD. Thus, it would seem that although the majority of financial managers address their shareholders' exposure to the most dominant currency in the world in their risk management decision-making process, they ignore or are unable to manage the exposure to movements of the Australian dollar to the most dominant currency in the Asia region. Finally, the implementation of cross-sectional analysis does not support the prediction that an appreciation of the Australian dollar will have a positive effect on imports and a negative impact on exporters.

\section{References}

Adler, M., and Dumas, B. 1984. Exposure to currency risk: Definition and measurement. Financial Management 13: 41-50.

Amihud, Y. 1994. Evidence on exchange rates and valuation of equity shares. Chapter 1. In Y. Amihud and R.M. Levich (eds). Exchange Rates and Corporate Performance. New York: Irwin Professional Publishing.

Australian Bureau of Statistics. Australian National Accounts Input-Output Tables: 1993-94.

Australian Stock Exchange. Industry Classification Report: January 1997

Bartov, E., and Bodnar, G.M. 1994. Firm valuation, earnings expectations, and the exchange rate exposure effect. Journal of Finance 49: 1755-85

Bartov, E.; Bodnar, G.M.; and Kaul, A. 1996. Firm valuation, earnings 
expectations, and the exchange-rate exposure effect. Journal Of Financial Economics 42: 105-132.

Baum, C.F.; Caglayan, M.; and Barkoulas, J.T. 2000. Exchange rate uncertainty and firm profitability. Working Paper. Boston College.

Bodnar G.M., and Gentry W.M. 1993. Exchange rate exposure and industry characteristics: Evidence from Canada, Japan and the USA. Journal of International Money and Finance 12: 29-45.

Booth, L. 1996. On the nature of foreign exchange exposure. Journal of Multinational Financial Management 6: 1-24.

Booth, L., and Rotenberg, W. 1990. Assessing foreign exchange exposure: Theory and applications using Canadian firms. Journal of International Financial Management and Accounting 2: 1-23.

Chamberlain, S.; Howe, J.S.; and Popper, H. 1997. The exchange rate exposure of U.S. and Japanese banking institutions. Journal of Banking and Finance 21: 871-892.

Choi, J.J.; Hiraki, T.; and Takezawa, N. 1998. Is foreign risk priced in the Japanese stock market? Journal of Financial and Quantitative Analysis 33: 361-382.

Chow, E.; Lee, W.; and Solt, M. 1997a. The economic exposure of US multinational firms. The Journal of Finance Research 20: 191 - 210.

Chow, E.; Lee, W.; and Solt, M. 1997b. The exchange rate exposure of US multinational firms. Journal of Business 70: 105-123.

Chow, E.H., and Chen, H.L. 1998. The determinants of foreign exchange rate exposure: Evidence on Japanese firms. Pacific-Basin Finance Journal 6: 153-174.

Clare, A.; Priestley, R.; and Thomas, S. 1997. Is beta dead? The role of alternative estimation methods. Applied Economic Letters 4: 559-562

Clare, A.; Priestley, R.; and Thomas, S. 1998. Reports of beta's death are premature: Evidence from the UK. Journal of Banking and Finance 22: 1207-1229.

Di Iorio, A., and Faff, R. 2000. An analysis of asymmetry in foreign currency exposure of the Australian equities market. Journal of Multinational Financial Management 10: 133-159.

Hansen, L. 1982. Large sample properties of generalized method of moments estimators. Econometrica 50: 1029-1054.

He, J., and $\mathrm{Ng}$, L. 1998. The foreign exchange exposure of Japanese multinational corporations. Journal of Finance 53: 733-753.

Jagannathan, R.; Kubota, K.; and Takehara, H. 1998. Relationship between the labor-income risk and average return: Empirical evidence from the Japanese stock market. Journal of Business 71: 319-347.

Jagannathan, R., and Wang, Z. 1996. The conditional CAPM and the crosssection of expected returns. Journal of Finance 51: 3-53.

Jorion, P. 1990. The exchange rate exposure of multinationals. Journal of 
Business 63: 331-342.

Khoo, A. 1994. Estimation of foreign exchange exposure: An application to mining companies in Australia. Journal of International Money and Finance 13: 342-363.

Leamer, E.E. 1983. Let's take the con out of Econometrics. American Economic Review 73: 31-43.

Levi, M. 1994. Evidence of exchange rates and valuation of firms. Chapter 3. In Y. Amihud and R.M. Levich (eds). Exchange Rates and Corporate Performance. New York: Irwin Professional Publishing.

Lo, A., and Mickinlay, C. 1990. Data snooping biases in tests of financial asset pricing models. Review of Financial Studies 3: 431-467.

Loudon, G. 1993. The foreign exchange operating exposure of Australian stocks. Accounting \& Finance 32: 19-32.

Prasad, A.M., and Rajan, M. 1995. The role of exchange and interest risk in equity valuation: A comparative study of international stock markets. Journal of Economics and Business 47: 457-472.

Shin, H.H., and Soenen, L. 1999. Exposure to currency risk by US multinational corporations. Journal of Multinational Financial Management 9: 195-207. 